\title{
Una Lección de Religión
}

\section{A class on Religious tolerance}

S eñor Editor: Todavía recuerdo con emoción el ueves Santo del año 2001. Una clase semanal del curso de Introducción a los Estudios Médicos para estudiantes de $1^{\mathrm{er}}$ Año de Medicina de la Pontificia Universidad Católica de Chile, se convirtió de pronto en una inesperada oportunidad de diálogo interreligioso.

Enseñando en una Escuela de Medicina de una Universidad que no sólo es católica sino además Pontificia, sentí que no podía comenzar la actividad docente tal como estaba planificada sin hacer alguna referencia a que ese día era un Jueves Santo. Decidí comenzar la sesión matinal con una reflexión sobre el significado ancestral de la Pascua. Sabía que en el curso habían algunos estudiantes judíos, por lo que la noche antes había escogido una lectura relacionada con la Pascua tal como se menciona en el Antiguo Testamento, en vez de aquella referida a la Pasión de Nuestro Señor Jesucristo.

Partí con mis estudiantes recordando por qué Semana Santa se celebra cada año en una fecha distinta. Evocamos la tradición de los antiguos pastores, antepasados del pueblo hebreo, que celebraban cada año la Pascua del Cordero, el cual era sacrificado en la primera luna de la primavera (Éxodo 12,2). Luego los estudiantes mencionaron las plagas y el éxodo de Egipto, hablamos de cómo aquella fiesta pagana cobraba un nuevo sentido: la sangre del Cordero sellaba el pacto de Yavé con el pueblo que Él había escogido en medio de todos los demás pueblos. Un alumno levantó la mano y nos contó que en la actualidad el pueblo judío sigue preparando para esa fecha un pan sin levadura (pan ázimo), para recordar la premura con que tuvieron que salir de Egipto: no habían tenido tiempo de agregar la levadura a la masa y, mientras la llevaban envuelta entre sus mantas, no alcanzó a fermentar. Una alumna dijo que este pan sin liudar

Correspondencia a: Dra. Sofía P. Salas. Marcoleta 391, Santiago. Fono (562): 354-8172. Fax (562) 632-1924. E mail: ssalas@med.puc.cl era también un símbolo de humildad y que nos recordaba el ser criaturas de Dios.

Otro alumno se levantó y dijo: yo ofrezco compartir con ustedes el pan sin levadura que traje de mi casa» Casi como en la escena de la multiplicación de los panes, esos tres matzohs»alcanzaron para más de ochenta personas. Mientras estos panes eran partidos y compartidos entre todos nosotros, leí el pámafo de la Biblia que había escogido la noche anterior: Ustedes celebrarán la fiesta de los Azimos en el día en que los hice salir de Egipto. Ustedes observarán este rito, y también lo observarán sus hijos para siempre.... Y cuando sus hijos les pregunten qué significa este rito, les responderán: Este es el sacrificio de la Pascua para Yavé, que pasó de largo por las casas de los hijos de Israel en Egipto....»(Éxodo 12,17 y 24-28). ¡Sin haberlo planificado, estábamos en cierta forma participando de una milenaria tradición judía al interior de una Escuela de Medicina católica!

Demás está decir que los tres alumnos que hablaron al final eran judíos. Ofrecieron, con mucha humildad y entrega, compartir sus tradiciones y su pan ázimo, tan cargado de simbología. Fueron, a su vez, acogidos por otro grupo de alumnos y profesores, de una religión distinta pero con igual origen, que los escucharon con respeto y cariño. Me atrevería a decir que varios de los presentes no olvidarán ese día y difícilmente lograremos otro momento tan espontáneo y de tanta unión como aquél.

Esta experiencia refleja algunas de aquellas virtudes que quisiéramos transmitir a nuestros alumnos de medicina: ser capaces de defender sus ideas y valores, aunque estén en minona; humildad para compartir, aunque lo que tengamos pueda ser considerado poco; y también tolerancia para acoger, escuchar y aprender de los que piensan distinto. En mi memoria, la sigo recordando como un momento de encuentro interreligioso y de paz.

\section{Sofía P. Salas}

Departamento de Obstetricia y Ginecología. Escuela de Medicina. Pontificia Universidad Católica de Chile. Santiago de Chile. 